\title{
Political Corruption, Judicial Selection, AND THE RULE OF LAW
}

\section{F.C. DECOSTE}

In this article, the author criticizes the current procedures used to appoint Canadian judges to provincial superior courts and to the federal court. The author begins with an examination of political corruption, which in his view depends upon the concept of the Rule of Law. The author proceeds with a detailed analysis of that concept, and concludes that current judicial selection procedures corrupt public authority and judicial office because they violate the institutional, moral, and ethical requirements of the Rule of Law. The author then reflects upon the wider social implications of such corruption.
Dans cet article, l'auteur critique les procédures actuelles de nomination de juges aux cours supérieures provinciales et fédérales du Canada. $L$ 'auteur examine d'abord la corruption politique, qui selon lui, dépend de la primauté du droit. $L$ 'auteur continue par une analyse détaillée de ce concept et conclut que les méthodes de sélection judiciaire actuelles mènent d̀ la corruption des pouvoirs publics et du système judiciaire parce qu'ils représentent une infraction des exigences institutionnelles, morales et éthiques de la primauté du droit L'auteur se penche ensuite sur les implications sociales plus larges d'une telle corruption.

\section{TABLE OF CONTENTS}

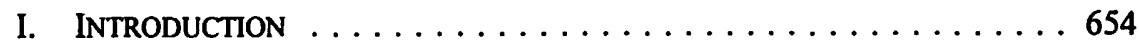

II. POLITICAL CORRUPTION $\ldots \ldots \ldots \ldots \ldots \ldots \ldots \ldots \ldots \ldots 6 . \ldots \ldots 65$

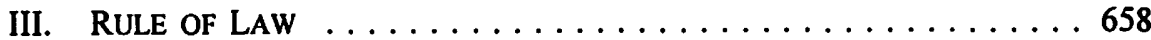

IV. CORRUPT AUTHORITY/CORRUPT OFFICE $\ldots \ldots \ldots \ldots \ldots \ldots 672$

A. SEPARATION OF POWERS $\ldots \ldots \ldots \ldots \ldots \ldots \ldots \ldots 673$

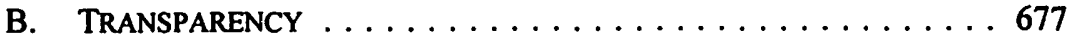

C. Judicial OfFICE $\ldots \ldots \ldots \ldots \ldots \ldots \ldots \ldots \ldots \ldots \ldots$

V. CONCLUSION ........................6. 680

That they may do evil with both hands earnestly, the prince asketh, and the judge asketh for a reward; and the great man, he uttereth his mischievous desire....

Micah 7:3

The social service which the judge renders to the community is the removal of a sense of injustice.

\section{Lord Devlin ${ }^{1}$}

\section{INTRODUCTION}

The Psalmist's point is "not just that 'power tends to corrupt', though it does, but that the values which politicians find themselves driven to promote, and others find 
themselves driven to endorse, may be the product of degraded social circumstances and arrangements." And his Lordship's point, surely, is that the meter of legitimacy of what judges do is justice. I want to propose that these understandings of the way of the political world, one ancient and one modern, converge in the matter of judicial selection at least so far as that matter is practised in Canada. ${ }^{3}$ I shall propose, that as assessed against the requirements of the Rule of Law, the procedures used to select Canadian judges involve decision-makers and candidates alike in political corruption just because those procedures arise from degraded institutional arrangements. Though my argument, I think, applies equally to both federal and provincial appointments, I shall take as my focus three features of the procedure (described fully elsewhere in this collection) used to appoint judges to provincial superior courts and to the federal court: ${ }^{4}$ namely, that the power to appoint resides fully and finally in the federal executive; that the exercise of that power is opaque and incorporates no known grounds; and that candidates for federal judicial office are required to nominate themselves. This argument of course depends upon the meaning of political corruption and of Rule of Law; therefore, I shall pause on each before proceeding to the details of my proposal.

\section{Political Corruption}

Though it is sometimes termed "an essentially contested concept,"s political corruption may be distinguished from private corruption in three illuminating ways. First, the grounds upon which an accusation of political corruption are properly made differ substantially from those which support an accusation of private corruption. Whereas accusations of private corruption depend upon personal morality (that is, upon some conception of what it means to live a good life), to be cogent at all, accusations

C.A.J. Coady, "Politics and the problem of dirty hands" in Peter Singer, ed., $A$ Companion to Ethics (Oxford: Blackwell, 1993) 373 at 379.

For a handy and insightful analysis of selection procedures in other liberal democratic states, see J. Bell, Policy Arguments in Judicial Decisions (Oxford: Clarendon Press, 1983) at 256-64.

I shall not deal directly with appointments to the Supreme Court of Canada. However, if the argument which follows is at all correct, then the procedure for those appointments (which is to say, prime ministerial fiat) is even more violative of political morality than is the procedure for appointment to the superior courts and the federal court. Indeed, inasmuch as appointments to the Supreme Court are a matter, purely or primarily, of prime ministerial will, they are a consequence and an instance of despotic governance which not only violates, but fundamentally contradicts, liberal political morality and Rule of Law. The very same can be said of the procedure for the appointment of chief justices to the Supreme Court, the provincial superior courts, and the federal court: whether made by the Prime Minister or by the Minister of Justice, these appointments ridicule the very notion of government by law. On the definition of despotic governance as one in which will is supreme, see C.H. Mcllwain, "Government By Law" in C.H. Mcllwain, ed., Constitutionalism and the Changing World (Cambridge: Cambridge University Press, 1939) 266; A.M. Cohler, B.C. Miller \& H.S. Stone, eds., Montesquieu: The Spirit of the Laws (Cambridge: Cambridge University Press, 1989) at 63; and Todorov's commentary on Montesquieu in T. Todorov, On Human Diversity: Nationalism, Racism and Exoticism in French Thought, trans. C. Porter (Cambridge, MA: Harvard University Press, 1993) c. 5, especially at 372-77. ("Despotism is a translation, on the social level, of features that characterize every human being: passion, the desire for power, the will to unify": ibid. at 377). For an insightful commentary on appointments to the Supreme Court, see J.S. Ziegel, "Merit Selection and Democratization of Appointments to the Supreme Court of Canada" (1999) 5:2 Choices 3. Institute for Constitutional \& Legislative Policy, 1994) 15 at 15. 
of corruption of a distinctively political kind must arise from some articulated view of political morality. Unlike personal morality, political morality concerns itself not with individual good, but with the good of political community; and its objects are "the fundamental bases of political life," and not the ends of human life well lived. ${ }^{6}$ Political corruption may, therefore, be properly (and I think uncontroversially) defined as "the debasement of the foundations or origins of a political community."

That the grounds of political and private corruption differ in these ways means as well that political and private corruption may be distinguished with regard to both their moral object and their accusatory force. These distinctions are especially important for present purposes, and some care is required in their formulation. Accusations of both private and political corruption may take as their meter either institutional or personal morality. ${ }^{8}$ The object of institutional morality is the identity and order of those structures required for the right conduct of some form of communal life. Personal morality, on the other hand, concerns the behaviour of individuals. Sometimes, however, personal morality is dependent upon, and derives from, institutional morality, and when that is the case we call the morality which governs personal conduct a role morality. Consider, for example, marriage: because we think being a spouse changes one's moral status, we hold spouses to an elevated and special standard in their personal behaviour, and that standard is defined by the morality which governs marriage as an institution.

Now, since spousal behaviour is a private matter, it is clear that, in some cases at least, ${ }^{9}$ accusations of private corruption may depend upon institutional morality and an associated role morality. However, such cases are relatively rare and, in any event, private corruption stands in stark contrast to political corruption in this respect. For, unlike private corruption which is only sometimes institution- and role-dependent, political corruption always and necessarily is so dependent. It is for just this reason that we can distinguish cases of conventional private corruption by public officials from cases of distinctively political corruption by them. ${ }^{10}$ Were, for instance, a public

$6 \quad$ S.M. Shumer, "Machiavelli: Republican Politics and Its Corruption" (1979) 7 Political Theory 5 at 8. For the distinction between public and private morality, see the essays collected in: S. Hampshire, ed., Public and Private Morality (Cambridge: Cambridge University Press, 1978); and S.I. Benn \& G.F. Gaus, eds., Public and Private in Social Life (London: Croom Helm, 1983).

$7 \quad$ J.P. Euben, "On Political Corruption" (1978) 36 Antioch Rev. 103 at 103. See also: W.J. Meyer, "Political Ethics and Political Authority" (1975) 86 Ethics 61 at $62-63$ (associating political corruption with "political morality," that "systematic ethical view ... that defines right and wrong in the realm of politics").

8 The distinction between the "institutional" and the "personal" does not exhaust the distinctions possible, at least as far as political corruption is concerned. Alatas, for instance, has constructed a comprehensive taxonomy based on a distinction between what he calls "transactive" and "extortive" corruption around which other types of corruption, including "nepotistic," "supportive," "autogenic," "defensive," and "investive" comption, purportedly revolve. See S.H. Alatas, Corruption: Its Nature, Causes, and Consequences (Aldershot: Avebury, 1990) c. 1. See also: M. Levi \& D. Nelken, eds., The Corruption of Politics and the Politics of Corruption (Oxford: Blackwell, 1996).

9 The position of university professors is another example. About which, see B. Wilshire, The Moral Collapse of the University (Albany: State University of New York Press, 1990).

10 This distinction is, of course, foundational to the rules of tort law which govern the liability of public officials. 
official to steal money, we should think his failure a private one just because stealing is not corruption by force of the institutional or role moralities which govern political life, but corruption by virtue of what might be termed a rare universal aspect of personal morality. "[S]uch misconduct," that is, "is not unique to politics nor does it constitute a violation of norms that are special to the realm of politics." II And because it is neither, such conduct, however deplorable we think it to be, does not compromise the institutional and role moralities which govern political community. I shall later claim that federal appointment procedures do both: that is, that in the respects noted previously, they violate the institutional morality of the liberal state and the role morality which that institutional morality requires, not only of judges, but of those who would be judges as well.

The third distinction resides in the comparative force of accusations of private and political corruption. Views of political morality are persuasive both to the extent that they fit, explain, and provide grounds for criticism of political arrangements and behaviours, and to the extent that they, in consequence, attract agreement among reasonably informed persons. If a view of political morality is defensible in this sense, then accusations of political corruption which are based upon it are particularly telling because they may be elided only on the condition that the accused either contests accepted standards of rationality or denounces the prevailing agreement. Because of the controversial nature of personal morality - ours after all is a society, as Dworkin so aptly puts it, "divided in project, interest, and conviction"12 - accusations of private corruption are much less forceful. This is so even with respect to accusations which arise from institutional and role morality, say spousal morality, because our moral dissensus often descends so deeply as to contest the morality of such institutional moralities. Indeed, it is only at the core of moral consensus that accusations of private corruption approximate the bite of accusations of political corruption. But that core is narrow indeed and, as Hart reminded us, probably extends no further than the morality of security of persons, property, and promises. ${ }^{13}$ That limited morality aside, then, it is a proper response to an accusation of private corruption that the accused does not share the personal morality which grounds the accuser's criticism. No such freedom of moral manoeuvre is available to one who stands accused of political corruption, provided the view of political morality from which it arises meets the standards of rationality and agreement, because such a view will be one which accounts for the moral dissensus which characterizes societies such as ours.

For this reason, it is quite proper to characterize political corruption, but not private corruption, as "a systemic concept," since "[p]olitical corruption violates and undermines the norms of the system of public order," and not just the dictates of some, generally contestable, view of personal morality. ${ }^{14}$ 
My accusation of political corruption in the selection of federal judges depends therefore on three grounds: that the Rule of Law is (at least the core of) the political morality of societies such as ours; and that the conception of Rule of Law from which I proceed (and the role morality and ethics which I think it entails) meets the standards of rationality and reasonable agreement. These matters must be addressed before I turn to the accusation proper, though I should caution that I can here do no more than sketch the argument which would fully establish these grounds of criticism.

\section{RULE OF LAW}

The Rule of Law is "the stable, durable core" of the political morality of political communities devoted to moral equality and to political and personal liberty and, in such societies, it is the Rule of Law which grounds at least the more serious accusations of political corruption. ${ }^{15}$ To say that the Rule of Law is the core of political morality is to claim: that in societies such as ours, the Rule of Law is the fundament of our "mode of association" (of our "mode of human relationship"); that the institutional arrangements of political community, and especially their legitimacy, express and devolve from that core; and that whatever other principles may govern political community (say for example, equality of opportunity), they are secondary, derivative, and in the result, contestable in ways that the core principle is not. ${ }^{16}$

Yet, despite its long-recognized centrality to our political arrangements, ${ }^{17}$ there is an enduring contest about the meaning and, particularly, the ambit of Rule of Law and, in the result, about its institutional requirements and even the contours of the role

Meyer, supra note 7 at 67. See also: P. Craig, "Formal and Substantive Conceptions of the Rule of Law: An Analytical Framework" [1997] Public L. 467 at 487 ("the rule of law is rightly regarded as a central principle of constitutional governance."); T.R.S. Allan, "The Rule of Law as the Rule of Reason: Consent and Constitutionalism" (1999) 115 L.Q. Rev. 221 at 222 (arguing that "the liberal ideal of the rule of law" is "the core of the liberal ideal of $\square$ government"); and (even) J. Raz, "The Rule of Law and Its Virtue" (1977) 93 L.Q. Rev. 195 at 205 ("The rule of law provides the foundation for the legal respect for human dignity").

See M. Oakeshott, "The Rule of Law" in On History and Other Essays (Oxford: Basil Blackwell, 1983) 119 at 119-20. See also Allan, ibid. (arguing that the rule of law is constitutive of liberal political community).

The status of such secondary principles, and the place of distributive justice particularly, in liberal theory is notoriously difficult. See for example: R. Ashcraf, "Liberalism and the Problem of Poverty" (1993) 6 Critical Rev. 493; B. Scheuerman, "The Rule of Law and the Welfare State: Toward a New Synthesis" (1994) 22 Politics \& Society 195; N. Lacey, "Theories of Justice and the Welfare State" (1992) I Social \& Legal Studies 323; D. Miller, "Distributive Justice: What the People Think" (1992) 102 Ethics 555; and, especially, E. Weinrib, "Legal Formalism: On the Immanent Rationality of Law" (1988) 97 Yale L.J. 509 (arguing, inter alia, that the purpose of litigation - and the end of adjudication - is corrective justice and not wealth redistribution). (Menlo Park, CA: Institute for Humane Studies, 1975). See also: A.V. Dicey, Introduction to the Study of the Law of the Constitution, 8th ed. (London: Macmillan, 1915); and, more recently, T.R.S. Allan, Law, Liberty, and Justice: The Legal Foundations of British Constitutionalism (Oxford: Clarendon Press, 1993). 
moralities which properly govern public officials such as judges. ${ }^{18}$ This debate centres on whether the Rule of Law requires merely rule by rules (whatever they might be) or whether, instead, the Rule of Law requires rules by rules of a specific sort. According to the first view, the virtues of the Rule of Law reside in the formal characteristics of rules as such - that is, their generality, prior declaration, clarity, and so on. ${ }^{19}$ According to the second view, the Rule of Law, though it presumes these general formal features of governance by rules, ${ }^{20}$ contains stipulations "about the content of the rules."21 In the contemporary academy the former view is most often associated with Joseph Raz, and the latter with Ronald Dworkin. ${ }^{22}$

Happily, present purposes do not require taking sides in this debate since the accusations of political corruption in judicial selection, which I will level in the next section, can reside easily on the more modest (and less controversial) foundations of the formalist conception of the Rule of Law. ${ }^{23}$ What I must do, however, is explore

See for example: R. Dworkin, "Political Judges and the Rule of Law" in A Matter of Principle (Cambridge, MA: Harvard University Press, 1985) 9 (contrasting what he terms "the 'rule-book' conception" of the rule of law to his "'rights' conception"); Craig, supra note 15; G.P. Fletcher, The Basic Concepts of Legal Thought (Oxford: Oxford University Press, 1996) at 14 ("No one has yet given an adequate account ... of the ideal conception of the rule of law."); $\mathbf{R}$. Westmoreland, "Hayek: The Rule of Law or The Law of Rules" (1998) 17 Law \& Philosophy 77; W.E. Scheuerman, "The Rule of Law at Century's End" (1997) 25 Political Theory 740; and, more generally, D. Dyzenhaus, ed., Recrafting The Rule of Law: The Limits of Legal Order (Oxford: Hart, 1999).

Justice McLachlin's claim of some years ago that "[t]he term 'Rule of Law' means many things to many people," remains therefore an apt description of academic debate. For her ladyship's commentary, see B. McLachlin, "Rules and Discretion in the Governance of Canada" (1992) 56 Sask. L. Rev. 167 at 168 . For the view that rule of law is an essentially contested concept, see M.J. Radin, "Reconsidering The Rule of Law" (1989) 69 Boston U.L. Rev. 781 at 783-92. And for the view that the term has been used "promiscuous[ly]," see Raz, supra note 15 at 196.

Perhaps, the best statement of these virtues is Fuller's: see L.L. Fuller, The Morality of Law, rev. ed. (New Haven: Yale University Press, 1969) c. 2. But Fuller is not alone in this. See also F.A. Hayek, The Constitution of Liberty (Chicago: University of Chicago Press, 1944) at 148-53 (rule of law means governance by general and settled rules impartially applied); and Raz, ibid., at 200 (rule of law means governance "by open, stable, clear and general rules"). That all three draw from a formalist core a host of associated virtues - chief among which is, as put by Raz "The independence of the judiciary must be guaranteed" (ibid. at 200) - is, as we shall see momentarily, crucial to my argument. For other demonstrations of the ineluctable fecundity of the formalist view, see J. Rawls, A Theory of Justice (Cambridge, MA: Belknap Press, 1971) at 23843; and R.S. Summers, "A Formal Theory of the Rule of Law" (1993) 6 Ratio Juris 127.

See for example Dworkin, supra note 18 at 11-12 (arguing that the virtues of rules identified by the formal conception of the rule of law are necessary ingredients of any acceptable theory of justice and, especially, that the formal conception is "relevant" to determining "whether the plaintiff has the moral right to receive, in court, what he or she or it demands." lbid. at 16).

Dworkin, ibid. at 11: what he calls "the 'rights' conception ... assumes that citizens have moral rights and duties with respect to one another, and political rights against the state as a whole. It insists that these moral and political rights be recognized in positive law, so that they may be enforced upon the demand of individual citizens through courts or other judicial institutions of the familiar type, so far as this is practicable." [emphasis in original]. Dworkin, ibid:; Raz, supra note 15.

23 I should add that in my view, on close examination, the dichotomy between formal and substantive conceptions of rule of law is not sustainable. Though space and purpose prevent my pursuing this line of inquiry here, such an argument is available from the concept itself: if the term "Rule of Law" properly denotes "constraint of power" (and not as Raz, for instance, would have it, 
the foundations and requirements of that conception in finer detail. In order to do that, it will be necessary first to elucidate the concept of the Rule of Law itself; the concept, that is, of which both the formalist and the substantive views are conceptions. Only then may institutional and role morality requirements be teased out of the formalist conception, which we will discover in these respects to be considerably less timid than it might otherwise appear.

According to the formalist conception, Rule of Law means governance "by rules fixed and announced beforehand." ${ }^{24}$ It is often times forgotten, I think, that this conception prescribes constraint (as do, by more robust means, the various so-called substantive conceptions) because it is a conception of the concept "rule of law" and, more specifically, because that concept has as its substance the constraint of power of, and by, the state. ${ }^{25}$ Before inquiring after the institutional architecture that ensues from the formalist conception of constraint (an architecture, incidentally, presumed as well by the substantive conceptions), it would perhaps be prudent to credentialize this understanding of the concept "Rule of Law."

That the term "Rule of Law" denotes, and prescribes, the political practice of constraining power ${ }^{26}$ - social power as well as political power - is not itself without

"guidance") then (a) the difference between the so-called formal and substantive conceptions is a difference of degree and not of kind; and (b) any such difference is attributable to a theorist's understanding of what "constraint" may properly include and require. See further infra notes 26 to 41 and accompanying text.

F.A. Hayek, The Road to Serfdom (Chicago: University of Chicago Press, 1944) at 72. See also A. Scalia, "The Rule of Law as a Law of Rules" (1989) 56 U. Chi. L. Rev. 1175; and, especially, Summers, supra note 19.

We shall see in a moment that, though it accords with both liberal political history and philosophy, even this minimalist statement of the concept has failed to attract complete consensus.

It is not difficult to credentialize this understanding of the concept across a wider variety of disciplinary and ideological positions. See, for example, G. Woodbind, ed., Bracton on the Laws and Customs of England, Vol. 2, trans. S.E. Thome (Cambridge, MA: Harvard University Press, 1968) at 305 (in this seminal 1230 treatise, Bracton defines law as "the bridle of power"); Dicey, supra note 17 at xxxvii and 179-201 (arguing that the rule of law means "the absence of arbitrary power": ibid. at 185); Hayek, supra note 24 at 72 (arguing that, "stripped of all technicalities," the rule of law "means that government in all of its actions is bound by rules fixed and announced beforehand"); Dworkin, supra note 12 at 93 (arguing that "the most abstract and fundamental point of legal practice" - which is to say, "the concept of law" as such - "is to guide and constrain the power of government"); E.P.Thompson, Whigs and Hunters: The Origin of the Black Act (London: Allen Lane, 1975) at 258-66 (arguing that the rule of law - the imposition of "inhibitions upon power" - is "an unqualified human good": ibid. at 266); J. Jowell, "The Rule of Law Today" in J. Jowell \& D. Oliver, eds., The Changing Constitution, 3d ed. (Oxford: Clarendon Press, 1994) 57 at 78 (arguing that "[t]he Rule of Law provides a principle which requires feasible limits on official power so as to constrain abuses"); and Allan, supra note 15 at 223 (arguing that "the underlying point of the rule of law" is that laws "constitute a bulwark against the deprivation of liberty through the exercise of arbitrary power"). Indeed, even contemporary critics of liberalism take the rule of law as their target precisely because they understand its force to be a claim about constraining power in the service of liberty and equality. See for example R. M. Unger, Law in Modern Society: Toward a Criticism of Social Theory (New York: Free Press, 1976) at 176-81, 192-93 (arguing that, instead of constraining power, the rule of law in fact serves to mask and to legitimize inequalities of power). Finally, natural law theorists too construe the point of the rule of law to be the constraint of power: see J. Finnis, Natural Law and Natural Rights (Oxford: Clarendon Press, 1980) at 270-76. 
contest. Some theorists instead think that Rule of Law, as a concept, concerns the provision of effective guidance to citizens. For instance, in his widely influential essay, "The Rule of Law and Its Virtue," Raz claims that "the rule of law ... has two aspects: (1) that people should be ruled by the law and obey it, and (2) that the law should be such that people will be able to be guided by it."27 This dissent from the dominant view is important for present purposes, not because there exists some correspondence between either concept and either conception - there isn' $t^{28}$ - but simply because criticism of the dissent, however brief, may serve to disclose the substance of the Rule of Law as a constraint concept in finer detail. We shall then proceed to the institutional requirements of the formalist conception which ground my argument against the selection process.

The "guidance" concept of Rule of Law is misconceived because it misses the fact that Rule of Law is a distinctly liberal accomplishment and aspiration; in the result, the "guidance" concept is unacceptable both as history and as theory. "The rule of law has traditionally been regarded as a vital protection of the citizen against arbitrary exercise of power," ${ }^{30}$ and "the law [as] a bulwark between governors and governed," ${ }^{, 31}$ precisely because the Rule of Law was articulated through, and served as an inspiration for, the centuries-long struggle for liberal politics. ${ }^{32}$ To separate the

Supra note 15 at 198. See also Fuller, supra note 19 (law is "the enterprise of subjecting human conduct to the governance of rules," ibid. at 96; to constitute a "system of law," rules must be able to guide human behaviour; and to guide human behaviour, rules must exhibit the virtues of rule of law, ibid. at 39). But see also his "A Reply to My Critics," ibid. at 187-242 (where Fuller appears to move towards the "law as constraint" concept), and Allan's commentary on this shift, supra note 15 at $225-27$.

Formalist and substantive conceptions of rule of law are wedded to neither concept. For instance, though Raz (ibid.) derives a formalist conception from the "guidance" concept, Hayek (supra notes $17,19,24)$ derives a no less formalist conception from the "constraint" concept. And though it might be true that most theorists who adopt a substantive view begin with the constraint concept, the constraint concept, in my view, does not compel, logically or otherwise, this result.

This may have to do with the universalist ambitions of legal theory at the time in which the "guidance" concept was articulated. For instance, in "The Rule of Law and Its Virtue" (supra note 15 at 202-205), Raz takes particular pains - as did Hart in The Concept of Law (supra note 13) - to distance his views from political philosophy of any sort in order to convince that his view of matters has pan-political application. This intention led Raz to argue (unsuccessfully we shall discover) that "[M]any forms of arbitrary rule are compatible with the rule of law. A ruler can promote general rules based on whim or self-interest, etc., without offending the rule of law": ibid. at 202-203. It is notable that, in his most recent works, Raz has backed away from this position, see, J. Raz, "The Politics of the Rule of Law" in Ethics in the Public Domain: Essays in the Morality of Law and Politics (Oxford: Clarendon Press, 1994) at 362 (arguing that the Rule of Law concerns "the protection of the individual" and that Rule of Law "can only be achieved in a country with a democratic culture and a culture of legality with a tradition of independence for the courts, the legal profession, the police, and the civil service"). Incidentally, there appears to be a correspondence between concepts of rule of law and the point of theoretical departure especially as regards the relationship between legal and political philosophy. To the extent that theorists think legal philosophy an independent enterprise, they will tend, I think, to be legal positivists and to adopt the guidance concept. Allan, supra note 15 at 228 .

Ibid.

For redactions of this history see Hayek, supra note 17; Thompson, supra note 26; and Summers, supra note 19. See also J. Brewer \& J. Styles, eds., An Ungovernable People: The English and Their Law in the Seventeenth and Eighteenth Centuries (New Brunswick: Rutgers University Press, 
Rule of Law from this history - to forget that "a government of laws and not of men" was a call for limited government ${ }^{33}$ - is fundamentally to misconstrue the political significance of Rule of Law. To do so, as Raz does, by domesticating and demeaning the concept, is also, however, to place oneself in a nearly impossible theoretical position. This is amply demonstrated by the difficulties with which Raz finds himself confronted in "The Rule of Law and Its Virtue." ${ }^{34}$

In order, he thinks, to discipline the use of the term (and thereby to salvage its continuing usefulness), Raz argues that the Rule of Law is about those virtues which legal systems must possess in order to provide citizens with guidance in following the law. ${ }^{35}$ But so conceived, the Rule of Law captures legal systems which the traditional "constraint" usage would exclude. Raz is clear about this:

A non-democratic legal system, based on the denial of human rights, on extensive poverty, on racial segregation, sexual inequalities and religious persecution may, in principle, conform to the requirements of the rule of law better than any of the legal systems of the more enlightened westem democracies. $^{36}$

So, judged by normal usage, Raz's usage is over-inclusive. But matters do not end there.

Raz also argues that "deliberate disregard for the rule of law violates human dignity" and that "[t]he rule of law provides the foundation for the legal respect for human dignity." ${ }^{37}$ Now if this is so, the question becomes: What then would motivate a state of the non-democratic kind that Raz thinks eligible for "Rule of Law" status nonetheless to subscribe to this fundament of respect for human dignity? Since it is he who is dissenting from traditional usage and from the wealth of historical evidence with respect to the proper meaning, it falls to Raz at least to attempt to answer, as he himself would frame the question, why such a regime would seek to "avoid[] evil" of this

1980); G.R.C. Davis, Magna Carta (London: British Museum Publications, 1977); and J.C. Holt, Magna Carta, 2d ed. (Cambridge: Cambridge University Press, 1992). That this history is primarily English history does not mean that other legal cultures, especially on the continent, did not participate in the intellectual development of Rule of Law. Regarding the former, see Montesquieu, supra note 4 at 156 (describing England as the "one nation in the world whose constitution has political liberty for its direct purpose"); and Hayek, supra note 17 at 15 (recounting David Hume's view that "the history of England was the evolution from a 'government of will to a government of law'"). Regarding the latter, see P. Manent, An Intellectual History of Liberalism, trans. R. Balinski (Princeton: Princeton University Press, 1994); and, for the German notion of Rechsstaat, see G. Dietze, Two Concepts of the Rule of Law (Indianapolis: Liberty Fund, 1973).

This well known call itself has English roots. See J. Harrington, The Oceana (1771) ed. J. Toland (Aalen: Scientia, 1963) at 37.

Supra note 15.

It is worth noting that, in declaring himself to be "following in the footsteps of Hayek and of many others who understood 'the rule of law' in similar ways" (ibid. at 196) Raz appears not to realize that his "guidance" view is a fundamental departure from the traditional "constraint" view endorsed by Hayek and most others.

Ibid. at 196. For Montesquieu's treatment of the problem of iniquitous laws and rule formalism, see Todorov, supra note 4 at 374-77.

Ibid. at 205. 
equality-diminishing kind. ${ }^{38}$ That he fails to do so indicates, ${ }^{39}$ I think, two further difficulties, namely, that he is conflicted about the reach of his view, and that his view cannot be sustained in the particulars to which it inevitably points. ${ }^{40}$ Those particulars include a host of matters - most especially, the separation of powers, the division between public and private law, transparency, and the special obligations of the legal community generally and the judiciary in particular - to which the constraint concept of the Rule of Law provides guidance and explanation where the guidance concept, even in Raz's sophisticated version, cannot. ${ }^{41}$

I am proceeding then on three bases: that Rule of Law means constraint of power of and through the state; that whatever the merits of the distinction between formal and substantive conceptions of that concept, ${ }^{42}$ certain formal institutional requirements constitute the core of conceptions of both sorts; and that, in order to qualify at all as a theory of the Rule of Law, a theory must both identify and explain those requirements. I am also proceeding on the view that those requirements, as defined by the more modest formalist conception, will properly found my condemnation of present procedures of selecting judges to our superior and federal courts. I have now then to articulate those requirements and will do so using Summers' "A Formal Theory of the Rule of Law."43

Ibid. at 206.

39 The answer which Raz does appear to provide - namely, that since "[t]he law inevitably creates a great danger of arbitrary power - the rule of law is designed to minimize the danger created by the law itself" (ibid. at 206) - will not do because it fails to answer why non-liberal states of the kinds he identifies would wish to eliminate such a danger; and because it seems to presume that rule of law is a corollary of law as such, a view from which he appears elsewhere to dissent (ibid. at 205-208). Moreover, his association of the rule of law with the constraint of power contradicts his view of "the basic intuition from which the doctrine of the rule of law derives," i.e., that "the law ... must be capable of guiding the behaviour of its subjects" (ibid. at 198). For a better argument regarding the relationship between rule of law, formally considered, and evil legal systems, see Summers, supra note 19 at 139-40 (arguing that "the institutional requisites of a formal theory of the rule of law and of substantive arbitrariness ... are in practice to a considerable degree incompatible"). Incidentally, regimes of the sort mentioned by Raz would lack even tactical motivation since whatever else may be said of it, the Rule of Law encumbers and, compared to the alternatives, renders inefficient, exercises of governmental power. Concerning the former, see supra note 29.

4 Save for the division between public and private law, Raz deals with each of these matters, at least by implication but in ways which his concept and his attempt to distance law and politics render most unsatisfactory. He is particularly unambiguous concerning the courts and the profession: "legal systems are based on judicial institutions" (supra note 15 at 206), and "the rule of law is ... among the few virtues of law which are the special responsibility of the courts and the legal profession" (ibid. at 208).

$42 \quad$ See supra note 23.

43 Supra note 19. I choose Summers for this purpose for a number of reasons. Firstly, he proceeds both from the constraint concept (ibid. at 127-28, 139) and from the view that the rule of law is a normative, liberal ideal (ibid. at 127, 129). Secondly, his conception is both decidedly formal, and encompasses both private and public law (ibid. at 129). Though he thinks, contrary to my own view (supra note 23), that there exists a "stark" distinction between formal and substantive conceptions, he also thinks, as do $\mathrm{I}$, that substantive conceptions have a formalist core (ibid. at 135-36). Finally, he thinks, as do I, that an adequate theory of the rule of law must articulate not only the independence of the judiciary, and of the legal profession more generally, but also "the special role" and obligation as regards the rule of law which that independence defines (ibid. at $128,130)$. 
If the Rule of Law is the constraint of power of and through the state, and if, minimally, the Rule of Law requires "governance by antecedent rule," inquire: how further might the Rule of Law, formally conceived, be characterized; and what is required, institutionally and morally, so that rule governance in the formal sense might indeed constrain power? Summers offers guidance on both matters. He characterizes the Rule of Law in the following fashion:

The ideal of the rule of law consists of the authorized governance of at least basic social relations between citizens and between citizens and their government so far as feasible through published formal rules congruently interpreted and applied, with the officialdom itself subject to rules defining the manner and limits of their activity, and with sanctions or other redress against citizens and officials for departures from rules being imposed only by impartial and independent courts or by similar tribunals, after due notice and opportunity for hearing."

From this statement, Summers proceeds to articulate what he calls "[t]he [i]nstitutional and [a]xiological [c]ore" of a formal theory of the Rule of Law as such. ${ }^{46}$ Though I will in a moment report his view of these matters, my intention is not simply to subscribe to Summers' understanding, but rather to use his views as an occasion to articulate what I take to be the proper expression and ambit of the core requirements of the Rule of Law and their consequences.

Summers identifies a host of "institutional forms" Law, both as theory and as practice. These include "rule making bodies, rules, sourceoriented criteria of validity, consistent and congruent interpretive method, reliable factfinding processes, an accessible, impartial, and independent judiciary, significant restrictions on the power of courts at point of application to modify antecedent rules, and ultimate imposition of remedies and sanctions only by courts or similar tribunals after due notice and opportunity to be heard." 48 So far as rules themselves are concerned, he largely adopts Fuller's account. ${ }^{49}$ That is, he thinks that rules of law "must not only be publicly known, but also be relatively constant through time, uniform across persons and other legal entities, free of conflict with other rules, and susceptible of compliance." Imo Importantly (and not just for present purposes), he associates with the independence requirement "procedures for the recruitment and retention of judges ... well-designed to secure judges ... with the requisite attitudes to law and law-like ways"sl; the existence of "a recognized, organized, and independent legal profession legally empowered and willing to advocate before courts the causes of citizens adversely affected by departures from the rule of law"s2; and the "special role" as

Ibid. at 135 .

Ibid. at 129.

Ibid. at 131 .

Ibid. at 135 .

Ibid.

Fuller, supra note 19.

Summers, supra note 19 at 129.

Ibid. at 130. See also Raz supra note 15 at 201 ("The rules concerning the independence of the judiciary - the method of appointing judges, their security of tenure, the way of fixing their salaries and other conditions of service - are designed to guarantee that they will be free from extraneous pressures and independent of all authority save that of the law").

Summers, ibid. 
regards the Rule of Law of which the members of the legal community - judges, academic and practising lawyers, and students of law alike - are seized just because they are, in his view, "the special clientele of the rule of law." 53 According to Summers, the Rule of Law also contains an "[a]xiological [c]omponent" consisting of certain "values" which "the rule of law characteristically serves." $54 \mathrm{He}$ places governmental legitimacy, "legislative and judicial as well as executive," as first among these values. ${ }^{55}$ Among the other values he names are "certainty and predictability of governmental action"; "private autonomy"; "respect for the dignity of the individual"; "freedom from arbitrariness of official action"; "natural justice"; "actual equality of legal treatment at the hands of the government" and "the appearance of actual equality of legal treatment"; and, importantly, "the reinforcement of the courage of officials to take unpopular decisions required by law."

If nothing else, Summers' redaction discloses that, as previously mentioned, the formal conception of the Rule of Law is much more robust than sometimes thought. It is pregnant with institutional prescriptions which are conceived as serving a host of values that together establish a meter for governmental legitimacy. ${ }^{57}$ In my view, however, despite this richness, his conception is confused. In particular, it fails sufficiently to categorize and connect the elements of the Rule of Law. This failure, I think, is a consequence of conceptual inadequacy. Because Summers does not conceive of the Rule of Law as the core of the political morality of the liberal state - and this despite his identification of most of the elements of that morality - he prevents himself access to the traditional doctrines which provide not only the lingua franca, but also the institutional architecture, of that morality. I want now to make good these inadequacies by situating Summers' suggestions in the doctrinal language of liberal politics.

The Rule of Law, I suggest above, ${ }^{58}$ is the indispensable core of the political morality of liberal states, of states devoted to treating their citizens with equal care and respect. The Rule of Law enjoys this primacy in liberal politics because its fundamental aim is the priority of justice (or that which persons are due) over power, and because the justice required by the Rule of Law is equality of treatment according to the rules of law. That it secures this priority through the state's constraint of power, has implications with respect to legitimacy to which we shall come in a moment and again in my argument against present selection procedures. What is presently before us is the nature of those institutionalized practices of constraining power of and through the state. As it turns out, this matter is not complex, at least not initially. The Rule of Law requires of states two primary institutional practices: the separation of powers and a regime of rules.

Ibid. at 128 [emphasis in original].

Ibid. at 131.

Ibid.

Ibid.

Nor, I caution, is Summers alone in this. Though, for the reasons previously mentioned (see supra note 43), I have chosen his views as a venue, the formalist theories of Raz and Rawls for example, exhibit very much the same richness. See supra notes $15,19$.

Supra note 15 and accompanying text. 
Allan observes that "the doctrine of the separation of powers is an implicit requirement of the rule of law." 59 Surely he is right since otherwise the independence of the judiciary, which all theorists think is a requirement of the Rule of Law, would have neither foundation nor defence. ${ }^{60}$ That doctrine requires that the judicial and political powers of the state each keep to its own respective realm: the judicial to the adjudicative, and the political to the legislative (rule-making) and executive (administration). ${ }^{61}$ Separation of powers is the first requirement and criterion of the Rule of Law since it alone ensures that the power of the state, which exists to constrain power, is itself constrained. And separation of powers founds not only the independence of the judiciary, ${ }^{62}$ which includes by all accounts the rules which govern the appointment of judges, ${ }^{63}$ but as well the existence of a free and self-governing profession from which the judiciary is drawn. It also has some very specific implications with respect to the obligations of the legal community - judicial, academic, and practising - to which we shall come.

Supra note 15 at 228. See also Hayek, supra note 19 at 210 (arguing that "the doctrine of the separation of powers must ... be regarded as an integral part of the rule of law"); Rt. Hon. B. Dickson, "The Rule of Law: Judicial Independence and the Separation of Powers" (Address to the Canadian Bar Association, 21 August 1985) [unpublished]; and W.R. Lederman, "The Independence of the Judiciary" (1956) 34 Can. Bar Rev. 769-809, 1139-79. Judicial independence is prescribed by both formal and substantive theories. See, for instance, Raz, supra note 15 at 200-201; Rawls, supra note 19; and Dworkin, supra note 18. About which, see M.J.C. Vile, Constitutionalism and the Separation of Powers (Oxford: Clarendon Press, 1967) at 13 ("Each branch of the government must be confined to the exercise of its own function and not allowed to encroach upon the functions of the other branches"); Hayek, supra note 19 at 210-12; Allan, supra note 15 at 228; F.C DeCoste, "The Separation of State Powers in Liberal Polity: Vriend v. Alberta" (1999) 44 McGill L.J. 231; and infra notes 124-32 and accompanying text.

It is a neat question "whether," as Hayek puts it, "the executive (or the administration) should be regarded as a distinct and separate power" co-equal with the other two (ibid. at 211). If one answers this question affirmatively, then parliamentary systems based on the British model (this of course includes Canada's) without more violate the separation of powers since such systems merge the legislative and the executive. See O.H. Phillips, "A Constitutional Myth: Separation of Powers" (1977) 93 L.Q. Rev. 11. As will become evident, this question has only incidental bearing on my argument regarding judicial selection since, under any view of the matter, the executive, like the other branches, is bound by clear, open, and prospective rules.

Blackstone's remains, in my view, the best statement of the principle of judicial independence:

In this distinct and separate existence of the judicial power in a peculiar body of men, nominated indeed, but not removable at pleasure, by the Crown, consists one main preservative of public liberty; which cannot subsist long in any state, unless the administration of common justice be in some degree separated from the legislative and also from the executive power. Were it joined with the legislative, the life, liberty, and property of the subject would be in the hands of arbitrary judges, whose decisions would then be regulated only by their own opinions, and not by any fundamental principles of law; which, though the legislatures may depart from them, yet judges are bound to observe.

Sce W. Blackstone, Commentaries on the Laws of England, 3d ed. (Oxford: Clarendon Press, 1765) at I, 269. See also W.O. Douglas, The Anatomy of Liberty: The Rights of Man Without Force (New York: Trident Press, 1963) at 88 (judicial independence alone prevents judges from becoming "instruments for expressing the whim or caprice of those in power"). For recent academic debate, see the essays collected in: "Judicial Independence and Accountability" (1998) 61:3 L. \& Contemp. Probs. 
The second requirement of the Rule of Law is a body of public rules to constrain public (political) and private (social) power. ${ }^{64}$ The rules of law are public rules in two specific senses: they have priority over all other rules by which we might chose to live our lives; and they apply comprehensively to all cases to which they properly relate, and independently from the assent of the individuals involved ${ }^{65}$ In order to qualify as a public rule, a rule must meet certain formal conditions. Variously stated, ${ }^{66}$ these conditions minimally include clarity, generality, openness, prospective and impartial application, and possible compliance. Together, these conditions construct a requirement of transparency: to qualify as a rule of law, under the Rule of Law, a rule must contain, and unambiguously communicate, specific, intelligible conditions for its application. ${ }^{67}$ Otherwise, it is no rule at all but instead a ruse to express and accomplish arbitrary power.

The Rule of Law defines the overall architecture of the regime of rules of which it primarily consists. That regime must contain rules of two sorts: rules of substantive law and rules of procedural law. Substantive law must also consist of rules of two sorts: rules of public law which govern the relations between citizens and the state, and rules of private law which govern the relations between persons. ${ }^{68}$ The Rule of Law requires both public law and private law because it seeks to constrain, as regards the security of persons and their property, both political and social power, that is, both the power of the state and the power of persons. Procedural law (the rules of evidence, process, and practice) regulates the conduct of appeals to the rules of substantive law by citizens and by the state. What are often referred to as the rules of natural justice are also procedural. Rules of this sort (chief among them are, of course, audi alteram partem and nemo iudex in re sua) are required by the Rule of Law because of the conditions which govern rule status, and also because of the requirement of judicial independence. $^{69}$

By political power, I mean the power to create rules for society and to have those rules enforced through agencies established for that purpose. Social power, on the other hand, is power residing in persons, individually or collectively, to affect the lives and plans of other persons. On social power, see A.L. Goldman, "Toward a Theory of Social Power" in S. Lukes, ed., Power (Oxford: Basil Blackwell, 1986) 156.

(6) See supra notes 19 and 49 and accompanying text.

67 On transparency, see P. Sztompka, "Trust, Distrust and Two Paradoxes of Democracy" (1998) 1 European Journal of Social Theory 19; D. Ivison, "The Art of Political Liberalism" (1995) 28 Canadian Journal of Political Science 203; J. Waldron, "Theoretical Foundations of Liberalism" in Liberal Rights (Cambridge: Cambridge University Press, 1993) 35 especially at 57-61; and J. Rawls, Political Liberalism (New York: Columbia University Press, 1993) at 66-71 (arguing that "the publicity condition" requires that "the grounds of [a society's] institutions should stand up to public scrutiny": ibid. at 68).

6 On public law, see M. Loughlin, Public Law and Political Theory (Oxford: Clarendon Press, 1992); and P.P. Craig, Public Law and Democracy in the United Kingdom and the United States of America (Oxford: Clarendon Press, 1990). On private law, see E.J. Weinrib, The Idea of Private Law (Cambridge, MA: Harvard University Press, 1995).

69 See P. Jackson, Natural Justice, 2d ed. (London: Sweet \& Maxwell, 1979); and J.R. Lucas, "Natural Justice and Process Values" in J.R. Lucas, ed., On Justice (Oxford: Clarendon Press, 1980) 72-98. 
A state structured and limited by the separation of powers, and subject to rules of substantive and procedural law, is a state which satisfies the requirements of legality. Legality, so understood, is an institutionalized morality concerning the constitution, exercise, and limits of power, and it is this morality which constitutes both the principle and the standard of state legitimacy. ${ }^{70}$ The Rule of Law state, that is, is no mere emanation of power, nor is it just the source of "coercive order"7!: it is instead a moral agent whose authority over the lives of people depends upon its continuing satisfaction of those conditions of legality. In a nice turn of phrase, Dicey named such a state as one characterized by "the predominance of the legal spirit."72 Before I proceed to the particulars of my charge against judicial selection, it is necessary to dwell on the ways in which the Rule of Law requires that the legal community generally, and judges in particular, serve as stewards and prophets of that spirit. ${ }^{73}$

We have seen that Summers holds the legal community as a whole to an elevated standard of fidelity to the Rule of Law because he thinks "students of the law, professional academics, legal practitioners and judges ... are the special clientele of the rule of law." from that ideal."" Judges must be seized of "the requisite attitudes to law and law-like ways"; the practising bar must stand ready "to advocate before the courts the causes of citizens adversely affected by departures from the rule of law"; and "academic lawyers must be ready to criticize not only rule departures but also any anti-rule of law attitudes of officials and judges, in particular." ${ }^{176}$ Raz too sets the legal community apart. In his earlier work, he argued that "the independence of the judiciary" (including "the method of appointing judges") is "essential for the preservation of the rule of law," and he placed the courts "in a central position ... in ensuring the rule of law." In a more recent work, he extends the requirement of independence to the legal profession as well and argues that the judiciary can remain independent "only if it is supported by a strong and independent legal profession." 78 I would, of course, dissent from none of this. However, I think more is needed, especially as far as judges are concerned. Whence their special role? And of what does it consist?

For law as "a series of institutionalisations," see J. Stone, The Province and Function of Law: Law as Logic Justice and Social Control (Sydney: Associated General, 1946) at 695-99. For Raz on "legal reasoning [as] an instance of moral reasoning" in a sense which seems to accord with my view of law as institutionalized morality, see "On the Autonomy of Legal Reasoning" in Ethics in the Public Domain, supra note 29 at 310-24.

Rawls, supra note 19 at 235.

Supra note 17 at 191.

I borrow the word "prophets" from Thomas Shaffer. See T.L. Shaffer, Faith and the Professions (Notre Dame: Notre Dame University Press, 1981) at 38 ("[L]awyers ... are prophets... They show their community what its values are and how much their values cost").

Supra note 19 at 128 [emphasis in original].

Ibid.

Ibid. at 130. With respect to academic lawyers, he adds the following understated caution: "That academics will stand ready to criticize rule departures should not be taken for granted. In many countries where academic lawyers frequently appear as advocates before courts there is often a deficiency of healthy academic criticism of any departures from the rule of law that may occur." Ibid. at 130, n. 4. 
I want to propose that the Rule of Law imposes two sorts of obligations on judges $^{79}$ : it requires judges to act, and not to act, in certain ways; and it requires them to be persons of a certain character. ${ }^{80}$ Requirements of the first sort (legal knowledge, impartiality, restraint, and so on) devolve both from the nature of public rules and from the separation of powers doctrine, and together they constitute what may properly be termed judicial morality, a matter which will not concern us here. ${ }^{81}$ Requirements of the second sort, those having to do with character and virtue, devolve directly from the Rule of Law as such, and they comprise the subject matter of judicial ethics. ${ }^{82}$ Judicial ethics is our concern since one of my arguments against present selection procedures

Though I will not dwell on the matter here, with some minor amendment, most of what I describe as judicial ethics applies as well to the practising and academic branches of the profession. This argument is framed in terms of the distinction between morality and ethics. Morality concerns itself with right conduct whereas the concern of ethics is right character; or otherwise put: morality is an answer to the question, "what should I do?" and ethics an answer to the question, "whom should I be?" In legal literature (especially the literature concerning professional responsibility) these terms are seldom used with any discipline and, in consequence, what generally passes as legal ethics is most often about legal morality, which is to say, about what lawyers and judges ought and ought not to do.

81 Though we shall see that there is a correlation between judicial morality and ethics: to wit, that adequate judicial performance morally depends upon judicial character and that, to the extent that judges are the wrong kind of people for their roles, they will be more likely to sin against the morality of restraint, impartiality, and so on. On the relationship more generally, see B. Williams, "Politics and Moral Character" in Hampshire, supra note 6 at 55-74.

There is a vast literature on (and, except at the margins, little controversy about) judicial morality. See for instance: J.T. Noonan Jr. \& K.I. Winston, eds., The Responsible Judge: Readings in Judicial Ethics (Westport: Praeger, 1993); J. Daley, "Defining Judicial Restraint" in T. Campbell \& J. Goldsworthy, eds., Judicial Power, Democracy and Legal Positivism (Dartmouth: Ashgate, 2000) 279; S.J. Burton, Judging in Good Faith (Cambridge: Clarendon Press, 1992); T. Bingham, "Judicial Ethics" in R. Cranston, ed., Legal Ethics and Professional Responsibility (Oxford: Clarendon Press, 1995) 35; M.H. Redish, "Abstention, Separation of Powers, and the Limits of the Judicial Function" (1984) 94 Yale L. J. 71; P.A. Talmadge, "Understanding the Limits of Power: Judicial Restraint in General Jurisdiction Court Systems" (1999) 22 Seattle U.L. Rev. 695; Lord Devlin, supra note 1; and B. Laskin, The Institutional Character of the Judge (Jerusalem: Magnes Press, 1972). On the morality of public officials more generally, see D.F. Thompson, Political Ethics and Public Office (Cambridge, MA: Harvard University Press, 1987).

In America, judicial morality has been codified in a canon of judicial ethics. See American Bar Association, "Model Code of Judicial Conduct (1990)" in T.D. Marshall, Judicial Conduct and Accountability (Scarborough: Carswell, 1995) 95-131. For commentary, see J.G. Riley, "Ethical Obligations of Judges" (1993) 23 Mem. St. U.L. Rev. 507; and A.M. Kennedy, "Judicial Ethics and the Rule of Law" (1996) St. Louis U.L. Rev. 1067. Canadian judges neither enjoy, nor are they subject to, a code of behaviour. The Canadian Judicial Council's Ethical Principles for Judges, which applies to all federally appointed judges, expressly prohibits its being used "as a code or a list of prohibited behaviours." Perhaps in consequence, the Principles reads more as a judicial anodyne than as a serious attempt to engage either judicial morality or judicial ethics. See Canadian Judicial Council, Ethical Principles for Judges (Ottawa: Canadian Judicial Council, 1998) (Chair: Chief Justice R.J. Scott) at 3 and passim.

There is also a literature on judicial ethics in this sense, though it is not nearly so vast as the literature on judicial morality. See for example L.B. Solum, "The Virtues and Vices of a Judge: An Aristotelian Guide to Judicial Selection" (1988) 61 S. Cal. L. Rev. 1735 (identifying judicial intelligence, integrity, and wisdom along with courage and good temper); B. Scharffs, "The Role of Humility in Exercising Practical Wisdom" (1998) 32 U.C. Davis L. Rev. 127; and P. Calamandrei, Eulogy of Judges, trans. J.C. Adams \& C.A. Phillips, Jr. (Philadelphia: American Law Institute/American Bar Association, 1992). Also see S. Macedo, Liberal Virtues (Oxford: Clarendon Press, 1990). 
depends upon one of the virtues which the Rule of Law requires of judges and of those who would serve the law as judges. Though my discussion of judicial ethics will be confined to that single virtue, I should indicate that, in my view, that virtue is primary and a complete theory of judicial ethics would necessarily begin with it and depend upon it. I shall attempt, therefore, to impart some measure of its full flavour and final importance.

Since the judicial branch is by all accounts specially burdened with "ensuring the rule of law," ${ }^{83}$ it makes sense to inquire what kind of persons judges must be in order to make good that responsibility. This is not to ask about the responsibilities which attach to the role of judge as such. It is rather to ask about the kinds of traits of character which individuals must possess in order adequately to appreciate and to faithfully to discharge those responsibilities. The contours of that role morality ${ }^{84}$ are not generally in dispute: the judge must have legal knowledge - which consists less of some catalogue of extant legal rules than of a sure lawyerly appreciation of the pattern and texture of the law as a whole - and must stand ready faithfully and impartially to dispense justice according to the rules of law. The matter of requisite character, though less often addressed, ${ }^{85}$ is in my view no more controversial, at least not at the core of the matter. The Rule of Law, I propose, requires above all else that judges be persons for whom the way of power in the world is a matter of much moral moment generally, and of abiding political suspicion in particular. This character trait (which, borrowing from Dworkin, I shall dub "protestant" ${ }^{86}$ ) devolves directly, and unavoidably, from the Rule of Law, or so I shall now very briefly argue.

I have so far proposed that the point of Rule of Law is the constraint of power and that law is therefore an institutionalized morality concerning the constitution, exercise, and limits of power. I want now to suggest that two very important consequences follow from this view of matters: first, that law is therefore subversive of power, and legal practice, judicial practice included, oppositional to power; and second, that the first virtue required of the judge is to be the kind of person for whom the law's public morality of constraint, subversion, and opposition is personal and partisan. Law is subversive of power for four very real and very practical reasons. ${ }^{87}$ First of all, law requires power (state power and private power) to respond in terms other than power itself, and because it does, law "introduces a breach in the unity of power" which without more compromises and destabilizes power ${ }^{88}$ Law approaches power with deep suspicion just because legality makes all power potentially subject to justification in terms of the universality and equality instantiated in the rules of law. This too subverts

Raz, supra note 15 at 201.

For a useful exploration of the notion of role morality, see A.I. Applbaum, Ethics for Adversaries: The Morality of Roles in Public and Professional Life (Princeton: Princeton University Press, 1999), especially c. 3 and 4.

See supra note 82 and accompanying text.

Supra note 12 at $190,252,413$.

I rely here on Todorov's commentary on Montesquieu, supra note 4. See also J. Vining, From Newton's Sleep (Princeton: Princeton University Press, 1995) at 208 (where Vining discusses "The Subversiveness of Law in the Twentieth Century").

Todorov, ibid. at 374 . Todorov also correctly characterizes "legality [as] force available to all" and as therefore an embodiment of the "sharing of powers" (ibid. at 374). The principle of legality is discussed supra notes 70-72 and accompanying text. 
power because it removes from power the solace of political insulation. Law sides with those who are vulnerable to power simply because it places the requirements of justice above the claims of power. This subverts power because the insistent demands of power to have its way in the world are made subordinate to the standards of right. Finally, law subverts power because, due to the universality and equality of legal rules, it tends to corrode the collectivities in which power tends to reside and to consolidate.

Now, none of this would surprise any lawyer worthy the name simply because the practice of law, in all its forms (private, academic, and judicial) is unavoidably oppositional. I mean by this, not that legal practice aims to eliminate power, but simply that it is necessarily about testing the limits and legitimacy of power in the lives of people and in the life of political community more generally. The private bar exists to counsel citizens about the claims of power, public and private, over their lives and, as put by Summers, sometimes "to advocate before courts the causes of citizens adversely affected by departures from the rule of law." 89 The academic branch of the profession exists both to transmit the tradition of the Rule of Law and, in its scholarship particularly, "to criticize not only rule departures but also any anti-rule of law attitudes of officials and judges, in particular." 90 And the judicial branch, of course, is burdened with determining, on the particular facts of individual lives, whether and when public or private power has exceeded the limits prescribed by the rules of law.

That law constrains power through an institutionalized practice of opposition and subversion means, I have suggested, that judges must be persons of a certain sort. Simply, they must be persons for whom the law's pledge of saving lives from illegitimate power is central to their self-understanding and motivation; they must, that is, be lawyers to their very roots, lawyers for whom Rule of Law is a vocation." Lawyers of this authentic kind are persons seized of what I have termed a "protestant" character. ${ }^{92}$ It is this trait of character, this attitude of distrust of power which surely arises from an habituated empathic imagination, ${ }^{93}$ that alone permits the judge to act as the faithful and partisan steward of the Rule of Law. Not only is the discharge of the requirements of judicial morality (especially competence and restraint) less likely in the

Supra note 19 at 130.

Ibid.

For a useful exploration of law as vocation, see C.F. Mooney, "Law: A Vocation to Justice and Love" in F.A. Eigo, ed., The Professions in Ethical Context (Philadelphia: Villanova University Press, 1986) 59. For a definition which contrasts vocation to "job" and "career," see R.N. Bellah, et al., Habits of the Heart: Individualism and Commitment in American Life (Berkeley: University of California Press, 1985) at 66.

92 See supra note 86 and accompanying text. Foucault's description of "the great civil lawyers of the eighteenth century" is apt: "The man of justice, the man of law, he who opposes to power, despotism, the abuses and arrogance of wealth, the universality of justice and the equity of an ideal law." See M. Foucault, Power, Truth, Strategy, ed. by M. Morris \& P. Patton (Sydney: Feral Publications, 1979) at 43 quoted in C. Douzinas \& R. Warrington, Justice Miscarried: Ethics, Aesthetics and the Law (New York: Harvester Wheatsheaf, 1994) at 15.

Judith Shklar expresses this well: "To have no idea of what it means to be treated unjustly is to have no moral knowledge, no moral life." See J.N. Shklar, The Faces of Injustice (New Haven: Yale University Press, 1990). 
absence of this vocational character, other judicial virtues which come easily to mind (for instance, courage and humility) ${ }^{94}$ are inconceivable without it. ${ }^{95}$

So it is in two senses then that judges are, as Summers claims, "the special clientele of the rule of law"96: they stand in a special relationship to the Rule of Law, not only because they have special obligations to the Rule of Law, but also because the Rule of Law requires of them a disposition of character of a special sort. Moreover, if it is the case, in law at least, that ethics is prior to morality, then failure at this elemental ethical level makes impossible the vigilance on which the Rule of Law finally depends.

\section{CORRUPT Authority/CORRUPT OfFICE}

I have defined political corruption as "the debasement of the foundations or origins of a political community"97 and have claimed that, in societies such as ours, the Rule of Law, formally conceived, is the core measure of the health of politics. I want now to argue that the procedures used to select judges to our provincial superior courts and to the federal court corrupt public authority and judicial office because they violate the standards of political morality required of, and defined by, the Rule of Law. More particularly, I shall propose: (a) that the federal executive is accountable to no other body in the matter of appointing judges and that such a full and final appointment power violates the principle of separation of powers; (b) that because that power is constrained by no rules, its exercise violates the principle of transparency and is arbitrary and abusive; and (c) that the self-nomination required of candidates is a perversion of judicial office. But before I turn to those arguments, I should make clear what I am not proposing.

I am not accusing either the federal executive, or candidates for judicial office, of personal corruption. ${ }^{98}$ Though it may true in some, or perhaps even in many, cases, that the federal executive is motivated by a desire for power or by loyalty to political friends, my argument does not require that this be so nor, therefore, that I prove that it is so. ${ }^{99}$ Though some or even many candidates may be venal or suffer from cupidity or rapacity, my argument with respect to self-nomination does not depend on this being the case ${ }^{100}$ nor, certainly, upon their serving as appreciative satrapies after

About which, see Solum, supra note 82; and Scharffs, supra note 82.

On this interdependence of legal morality and ethics, see supra note 81 .

Summers, supra note 19 at 128 [emphasis in original].

Supra note 7 and accompanying text.

98

See supra notes 10 and 11 and accompanying text.

99

On the other hand, historically, the appointment process has most often been criticized for being corrupt for just these reasons. See M.L. Friedland, A Place Apart: Judicial Independence and Accountability in Canada (Ottawa: Canadian Judicial Council, 1995) at 234-43; and C. Kendall, "Criticism and Reform: A Survey of Canadian Literature on the Appointment of Judges" in Ontario Law Reform Commission, Appointing Judges: Philosophy, Politics and Practice (Toronto: Ontario Law Reform Commission, 1991) 211-31.

100 Though on the evidence available, lawyers seek and accept judicial appointments for reasons which are amazingly banal and self-serving. See P. McCormick \& I. Greene, Judges and Judging: Inside the Canadian Judicial System (Toronto: James Lorimer \& Company, 1990) at 84-100 (reporting the results of a survey of judges on why they became judges). For ruminations on the absence of public service motives among lawyers and judges, see R.B. McKay, "The Rise of the Justice 
appointment. ${ }^{101}$ On the other hand, my charge should not be construed as arising from a concern with "dirty hands." Indeed, if "the problem of dirty hands" concerns the violation of moral principles "for the sake of public purposes,"102 my judgment with respect to the federal executive would be that when, in the matter of judicial appointment, it violates core standards of personal morality, it does so for reasons more associated with the maintenance of the power to appoint, and of political power more generally, than with the promotion of some view of the common good. ${ }^{103}$ So far as candidates are concerned, even if there are some or even many who, though they appreciate the moral problems associated with the appointment procedure, proceed on the ground that the good of their future contributions will outbalance the dirtiness of becoming a judge, that calculation cannot, in my view, relieve moral blameworthiness. In such circumstances, rather, the moral response would be to decide against pursuing judicial office. ${ }^{104}$

\section{A. Separation of Powers}

Under present procedures, applicants for federal judicial office submit their wares $^{105}$ via the Office of the Commissioner for Federal Judicial Affairs to the Advisory Committee for the province or territory in which the candidate resides. ${ }^{106}$ Established in 1988 (with some minor changes introduced in 1991, 1994 and 1999), ${ }^{107}$ the job of the Advisory Committees is "to screen persons applying for judicial office and to advise the Minister of Justice whether the applicant is highly recommended, recommended, or not recommended." 108 Ziegel rightly reports that "most observers

Industry and the Decline of Legal Ethics" (1990) 68 Wash. U.L.Q. 829.

Indeed, my impression is just the opposite: rather than conceiving of itself as subordinate to the state, the present generation of judges, despite the manner of its appointment, appears intent on aggrandizing its status and power vis-a-vis the state. In the process, humility has been replaced by hubris and restraint by over-reach. The results of a recent survey of Canadian appellate court and Supreme Court judges lends some support to this view. See 1. Greene, et al., Final Appeal: Decision-Making in Canadian Courts of Appeal (Toronto: James Lorimer \& Company, 1998) at $127,129,200-201$ (reporting that a majority of appellate judges do not feel particularly constrained by precedent) and at 103, 183-86 (reporting that appellate judges are increasingly concerned about threats to judicial independence). See also my "Introduction" to this Special Issue (2000) 38 Alta. L. Rev. at 607; and J.S. Ziegel, "The Supreme Court Radicalizes Judicial Compensation" (1998) 9 Constitutional Forum 31.

Thompson, supra note 81 at 11. See also, S. Buckler, Dirty Hands: The Problem of Political Morality (Aldershot: Ashgate Publishing, 1993).

The implications of the federal state's continuing insistence on holding to itself the appointment power will be briefly canvassed in the conclusion to this essay. Thompson, supra note 81 at 15 .

Candidates display their wares in a form - the "Personal History Form," prescribed by the Office of the Commissioner for Federal Judicial Affairs. For which, see Appendix 4 to A.S. Millar, "The 'New' Federal Judicial Appointments Process: The First Ten Years" (2000) 38 Alta. L. Rev. 616 at 634 .

Until 1999, provincially appointed judges seeking elevation to provincial superior court or to the federal court were excluded entirely from this process. Since then, applications of this sort have been subject to Committee commentary but not assessment. Whatever the case with respect to applications by non-judges (and more on that in a moment) elevations remain entirely a matter at the discretion of the federal executive on the advice of the federal Minister of Justice. Millar, supra note 105.

108 J.S. Ziegel, "Appointments to the Supreme Court of Canada" (1994) 5 Constitutional Forum 10 at 13 [emphasis in original]. 
dismiss the advisory committees as little more than window dressing designed to detract attention from continuing complaints about the role of patronage appointments." 109 I do not dissent from this view. But in order to ground my argument with respect to the separation of powers, it will be necessary briefly to show why this is the case and why it is correct to claim, as I do, that despite the existence of the Advisory Committees, federal appointments remain a matter at the untrammelled discretion of the federal executive.

That this is so is easily demonstrated by considering the process of appointment to the Advisory Committees and their authority and practice. Presently, each provincial $^{110}$ and territorial committee has seven members, all of whom are appointed by the federal Minister of Justice for a three year term of office. "II Three of the appointments are at the Minister's own initiative; the remaining four are appointed on nomination from each of the provincial or territorial Chief Justice, Attorney General or Minister of Justice, Law Society, and Canadian Bar Association Branch. ${ }^{112}$ There are stated grounds for none of these appointments and, unless one attends slavishly to The Canada Gazette, even the current membership is a mystery. ${ }^{113}$

Neither the authority nor the practice of the committees improves this unhappy beginning. Simply stated, the committees have no authority to cabin the Minister's or the executive's discretion. Not only are they prohibited from initiating recruitment by seeking out candidates themselves, ${ }^{114}$ as regards the applications forwarded to them from the Office of the Commissioner of Federal Judicial Affairs, ${ }^{115}$ the committees' sole role is to vet the applications and report to the Minister in a prescribed form. ${ }^{116}$ The Minister, however, is not bound (certainly not by law or apparently by

note 105

III Members may be re-appointed for a single additional term.

112 Millar, supra note 105.

113 But see the very helpful summary of membership by committee 1989-1999 in Appendix 2 to Millar, ibid.

This prohibition does not apply to the Minister or to the Office of the Commissioner of Federal Judicial Affairs.

115

Before a candidate's file is forwarded to a committee, the Judicial Appointments Secretary screens applications to ensure that they meet statutory requirements and, on basis of information provided by the law society of which the candidate is a member, compiles a dossier containing information that "could affect the candidate's fitness for appointment." See Millar, supra note 105 at 622.

186 Since 1991, committees have been permitted to provide the Minister with a precis of the qualifications of candidates on which the committees' assessments - themselves runically prescribed: "highly recommended," "recommended," "unable to recommend" - are based. Incidentally, these assessments are presently valid for two years and, if a candidate is not appointed during that period and remains set on becoming a judge, the candidate may reapply. 
practice $)^{117}$ by the committees' deliberations: the Minister may appoint despite a committee's assessment, and may appoint persons not vetted by any committee. ${ }^{118}$

Committee practice reflects their subordination to the political. Committees are subject to political oversight since "[t]he Judicial Appointments Secretary, or the Commissioner of Federal Judicial Affairs, must attend each Committee meeting to record and certify Committee decisions prior to their submission to the Minister."119 With respect to the decisions themselves, committees appear guided more by evaluation by telephone consultation with select gate-keepers than by any objective criteria. ${ }^{120}$ Perhaps assessment by gossip is pre-eminent simply because no rules or procedures exist to guide committee deliberation. Committees do not interview candidates, ${ }^{121}$ and neither the application form (which, in addition to basic biography, asks applicants in a section entitled "Reasons For Your Candidature" essentially to reveal themselves in proper light) ${ }^{122}$ nor the stated criteria ${ }^{123}$ provide any real guidance. Finally, consistent with this overall lack of transparency, committees meet in secret and applicants, though they are informed of the date of their assessment, are not informed of the outcome.

For all of these reasons, the Advisory Committees, in my view, act to aid and abet executive discretion and not in any sense to constrain or diminish it. And because that discretion therefore survives untrammelled (though perhaps, as Ziegel suggests, in the

The appointment of politically-connected Halifax lawyer Heather Robertson to the Nova Scotia Supreme Court is illustrative. On first consideration, the Nova Scotia Advisory Committee reported to the Minister that it was "unable to recommend" Ms. Robertson. The Minister then remitted the matter to the Committee for reconsideration which practice, remarkably, is permitted by the federal ministry's self-defined protocol (as contained in its 1996 booklet on federal judicial appointments). On reassessment, the Committee found itself able to recommend Ms. Robertson who was sworn in as a justice of the Nova Scotia Supreme Court in August, 1998. Subsequently, Madame Justice Bateman of the Nova Scotia Court of Appeal resigned her position as the Chief Justice of Nova Scotia's nominee on the Advisory Committee, and the Nova Scotia branch of the Canadian Bar Association complained to the Minister about political interference in the assessment process. See C. Schmitz, "CBA Denounces Political Pressure in Screening Applicants for Bench" 18:14 The Lawyers Weekly (21 August 1998) 1, 29. That as recently as 1994, then Minister of Justice Rock found it necessary to give "his personal undertaking not to recommend to Cabinet any person not previously recommended by a Committee" underscores, I think, the sorry position of the advisory committees: their "authority" consists of scraps from the Minister's personal table. See Millar, supra note 105 at 620 . See also Friedland, supra note 99 at 240-42. Millar, ibid. And see supra note 115 (committee deliberation proceeds on basis of prior characterization of the candidacy by the Judicial Appointments Secretary). C. Schmitz, "Judge Selection Process Slammed" 18:6 The Lawyers Weekly (12 June, 1998) 1, 11 (quoting the then Liberal chair of the Commons Justice Committee's characterization of committee practice).

A procedure, incidentally, that has recently been adopted by the Province of Alberta for selecting candidates to provincial courts. See Alberta, Report and Recommendations: Judicial Selection Process Review Committee (Edmonton: Alberta Justice Communications, 1998). 
result politically insulated ${ }^{124}$ ), it is headlong at odds with the political morality of separation of powers.

It was Montesquieu's genius to discover ${ }^{125}$ what Todorov rightly calls "a universal principle of political life": ${ }^{26}$ that unaccountable power is arbitrary and abusive power, and that political power can only be held to account by the "ballast" of separation of powers. ${ }^{127}$ Montesquieu claimed that "political liberty ... is present only when power is not abused," and that for power not to be abused, "power must check power by the arrangement of things." 28 "In order," he thought, "to form a moderate government, one must combine powers, regulate them, temper them, make them act; one must give one power a ballast, so to speak, to put it in a position to resist another." ${ }^{129}$ This understanding led Montesquieu to distinguish between the legislative, executive, and judicial powers of the state, and to propose that "liberty is formed by a certain distribution of the three powers." 130 "When legislative power is united with executive power in a single person or a single body of the magistracy, there is no liberty.... Nor is there liberty if the power of judging is not separate from legislative power and from the executive power." ${ }^{131}$ This is so, he thought, because power will inevitably be abused unless one power "is chained to the other by their reciprocal faculty of vetoing,",132 or unless they are "counter-balanced." 133

The federal executive's power to appoint is neither chained nor counter-balanced. The executive is not accountable to the legislature for its actions nor has the legislature a part in the process. And though the judicial branch specifically, and the legal community more generally, have state-appointed representatives on the Advisory Committees, the committees act to obfuscate and legitimate the executive's continuing power to do as it pleases. ${ }^{134}$ Because it consists of pure discretion, the executive's

Supra note 108. The wisdom of this conclusion may be illustrated by what appears to be the government's initiative to manage the Robertson affair (supra note 117), by having the then Chair of the Commons Justice Committee attack the integrity of the Advisory Committees. See supra note 120.

"Discover" is perhaps too strong a word since the principle can be found in English politics and letters well before Montesquieu, though not in his fully articulated expression. I would date the English origins to the Magna Carta (1215) and to Henry de Bracton's De legibus et consuetudinibus Angliae, supra note 26 and trace its final pre-Montesquieu expression to John Locke. There is no doubt that Blackstone's expression of the doctrine in the Commentaries (supra note 62) was influenced by Montesquieu. For the history of the doctrine, see Hayek supra note 17 and Vile, supra note 61. For Locke's redaction, see J. Locke, The Second Treatise of Civil Government and A Letter Concerning Toleration, ed. by J.W. Gough (Oxford: Basil Blackwell, 1946) at 107, para. 222 (the end of "choos[ing] and authoris[ing] a legislative is that there may be laws made, and rules set ... to limit the power and moderate the dominion of every part and member of the society").

126 Supra note 4 at 375.

127 Montesquieu, supra note 4 at 63 (Book V., c. 4).

128 Ibid. at 155 (Book IX, c. 4).

129 Ibid. at 63 (Book V, c. 14).

130 Ibid. at 187 (Book XII, c. 1).

131 Ibid. at 157 (Book XI, c. 6).

132 Ibid. at 164 (Book XI, c. 6).

133 Ibid. at 182 (Book XI, c. 18)

134 In contributing to that result, the judicial and law society representatives contribute as well to diminishing the integrity of their respect communities. 
power of appointment is by definition arbitrary and abusive; and the exercise of such a power to appoint judges necessarily offends the independence of the judicial branch. Remember that the separation of powers alone founds that independence. ${ }^{135}$ Consequently, where as here judges are appointed in a manner which violates the doctrine of separation, the very structure which defines their independence, and their independence itself, is compromised, perhaps fatally so. Simply, judges who owe their office to the exercise of arbitrary power have, without more, forsaken the grounds of their independence.

\section{B. TRANSPARENCY}

Not only is the federal executive not accountable to any other branch, its power to appoint neither flows from, nor is it confined by, any rule. That the executive operates under a plenary grant of constitutional power does not change this result. ${ }^{136}$ Government by law requires that the state be itself subject to clear, general, and open rules. ${ }^{137}$ Where, as here, the rules declare that the government can do whatever it pleases $^{138}$ - that is, where they grant pure discretion and place no genuine restrictions on the actions of government - governmental action taken in their name is arbitrary and abusive, and a parody of the Rule of Law.

The lack of transparency in judicial selection is a direct and inevitable result of the executive's acting, in this fashion, beyond the law. I mention above ${ }^{139}$ that the requirement for clear, general, open, and prospective rules secures transparency. The reason is simple: by declaring beforehand the conditions of their application, rules disclose and make intelligible to all the nature and limits of governmental power. Where, as here, this is not the case, the result is not merely secrecy - what government after all would be keen on disclosing that its decisions are an exercise in pure power? - but violation of one of the foundational conditions of Rule by Law.

Transparency goes to the very heart of government by law. Unless political institutions are transparent, that is, unless they are capable of explaining and justifying themselves, not after the fact but through their ongoing, rule-governed practices, then the very notion of constraint of power, and of liberty and equal treatment, becomes jest. For, absent such rules, rules which are "well-known and available for public apprehension and scrutiny," governmental action must be driven by power and must

See supra notes 59-63 and accompanying text.

136 See Constitution Act, 1867 (U.K.) 30 \& 31 Vict., c. 3, reprinted in R.S.C. 1985, App. II, No. 5, ss. 96 and 101.

137 Supra notes 64-67 and accompanying text.

138 It is not necessary that ss. 96 and 101 be read as rules at all, at least not in the normal sense. They are clearly constitutive rules and rules of that sort are best interpreted as invitations to frame rules to guide and constrain the grant of power. Such an interpretation would of course require a government which takes seriously the Rule of Law and, at least as far as judicial appointment is concerned, Canada has yet to blessed with such a government. On the distinction between constitutive and other rules, see F. Schauer, Playing By the Rules: A Philosophical Examination of Rule-based Decision-making in Law and Life (Oxford: Clarendon Press, 1991) at 6-7. On the obligation to frame rules which attends delegated power, see Hayek supra note 19 at 211. 
"depend on mythology, mystification, or a "noble lie." 140 In a very real sense, then, governments violate the Rule of Law to the extent that any of their practices rely on secrecy through discretion rather than on candour through rules. In the matter of judicial appointments, the federal government has placed fulsome reliance on the former.

\section{Judicial Office}

Vocations can be betrayed. ${ }^{141}$ Usually, they are betrayed through neglect. Lawyers, for instance, may neglect their obligations to clients or to other lawyers in an endless variety of ways and, in so doing, betray their vocation as stewards of the Rule of Law. But vocations may also be betrayed through perverse self-indulgence. This is what concerns us here. I shall argue that compliance with the requirement of self-nomination is an indulgence of self, which perverts judicial office.

Judicial decisions are decisions taken "by institutions, by people not acting for themselves but fulfilling a role of trust." 142 I have argued that in order to act on that trust, judges must be persons of a certain sort. ${ }^{143}$ Most especially, they must be persons for whom the public morality of the Rule of Law is personal: the law's suspicion of power and its opposition to arbitrary power must, that is, motivate and guide their lives. I want now to explore the attitude which judges, and those who would be judges, must take in order to meet this ethical requirement. Then I shall explain why self-nomination involves candidates in abandoning that attitude.

One of Herbert Hart's many enduring contributions to the law has been his specification of the attitude required of members of the legal community. ${ }^{144}$ According to Hart, to be lawyer at all is to adopt what he termed the internal point of view:

When a social group has certain rules of conduct ... it is possible to be concerned with the rules, either merely as an observer who does not himself accept them, or as a member of the group which accepts and uses them as guides to conduct. We may call these respectively the "external" and "internal" points of view. ${ }^{145}$

Lawyers, that is, must accept "the law as a set of rules with legitimacy and moral authority." 146 In order to do so, they must not only know generally what those rules are, but also make moral sense of them by discerning the background justification of

Waldron, supra note 67 at 58.

1 discuss law as vocation, supra note 91 and accompanying text.

Raz, supra note 29 at 323.

Supra notes 83-88, 91-96 and accompanying text.

Supra note 13 at $89-91,242-43,254$.

Ibid. at 86. See also: D.E. Litowitz, "Internal Versus External Perspectives on Law: Toward Mediation" (1998) 26 Fla. St. U.L. Rev. 127; B.Z. Tamanaha, "The Internal/External Distinction and the Notion of "Practice" in Legal Theory and Sociolegal Studies" (1996) 30 L. \& Society Rev. 163; R.L. Schwartz, "Intemal and External Method in the Study of Law" (1992) 11 L. \& Phil. 179; and R. Barnett, "The Internal and External Analysis of Concepts" (1990) 11 Cardozo L. Rev. 525. Litowitz, ibid. at 128. 
the bodies of law in which the different rules reside; this in turn requires that they discern the background justification of the law as a whole. ${ }^{147}$ Since the Rule of Law alone morally justifies governance by a body of coercive public rules, being a lawyer means accepting the Rule of Law, and all that it entails both morally and ethically.

The requirement, extant since $1988,{ }^{148}$ that candidates for federal judicial office nominate themselves requires, I want to suggest, that candidates abandon the internal point of view and therefore the ethical position with respect to power upon which the legitimacy of judicial office finally depends. Now, self-nomination might never be a prudent practice since it invites the venal and the rapacious every bit as much as it calls to those capable of conceiving of judicial office as public service. But whatever its merits more generally, under present procedures, self-nomination is repugnant because it requires candidates to acquiesce in, indeed to become accomplices to, the federal executive's flagrant abuse of its appointment power. Acquiescence is avoidable only for those who happen not to be seized of the spirit of legality. For the rest - may one hope, the majority? - the very submission of the application means acquiescence and complicity in arbitrary power. And that means, without more, the abandonment of the legal point of view. I suggested above ${ }^{149}$ that the calculation temporarily to suspend one's commitment to the law, on the intention of providing ethical public service later on, is itself morally indefensible. I will now add that, in my view, no such suspension is possible. The internal point of view is not fungible in this fashion simply because it is a committed decision about what matters in one's life at law. In consequence, the decision to acquiesce cannot be recuperated. Once made, it corrodes the quality of one's life in the law. So too for all of those who since 1988 have made this fateful decision: where they succeeded in becoming judges, the cost of the bargain has been the legitimacy of their office. For those oblivious to these moral complexities, no such decision was necessary; but of course, though present procedures may have satisfied their aspirations, their office was condemned $a b$ initio.

Hayek wisely counsels that "[t]he problem of discretionary power as it directly affects the rule of law is not a problem of the limitation of the powers of particular agents of government but of the limitation of the powers of the government as a whole." 150 So viewed, the procedures for judicial selection have a deep and wideranging significance. Not only do they corrupt executive and judicial authority, but in so doing, they compromise the legitimacy of the state as a whole. The causation is insidious. The federal executive adopts practices which corrupt not only its own authority, but the authority of the judicial branch to which those practices are directed, and of the legislative branch which those practices ignore. In this, the federal executive has stage-managed the compromise of the state's status as a moral agent. It arrogates arbitrary power to itself and consigns the legislative branch to impotence and the judicial branch to complicity. That this could so easily be otherwise makes the matter

For the notion of background justification, see Schauer, supra note 138 at 5, 26-27, 53-55, 73-76. This requirement was part of the "new" appointment process adopted under the guidance of then Minister of Justice Hnatyshyn. See Millar, supra note 105.

Supra note 104 and accompanying text.

Supra note 19 at 213. 
all the more tragic. Indeed, the federal state need only legislate clear and open rules for the appointment of judges: that is, it need only resolve to act as a Rule of Law state.

\section{Conclusion}

Corruption "measures the failure to reach the norms expected of healthy politics."ISI I have argued that, judged by the norms of the Rule of Law, the Canadian polity is sick indeed. The procedures used to appoint officers to the judicial branch not only exhaust the legitimacy of that branch, but those procedures critically compromise the legitimacy of the executive and legislative branches as well. That they have these effects illustrates both the fragility and the fundamental importance of legal culture. ${ }^{152}$ I have also argued that open and clear legislative rules are the simple and ready cure for this disease. ${ }^{153}$ Articulation of these rules is, however, beyond the remit of this essay. ${ }^{154}$ I wish instead to conclude by reflecting upon the wider social implications of this failure of Canadian politics.

I do not intend to make a sociological claim about the diminishment of public trust in government generally or in the judiciary in particular. Though "a culture of trust" is both a condition and a consequence of Rule of Law, ${ }^{155} \mathrm{I}$ am no sociologist; and in any case, the data that does exist suggests that Canadians are somewhat more likely to trust the judiciary than the other branches. ${ }^{156}$ What I want to briefly explore, rather, are the conditions which sustain the present decomposition of Canadian politics in this regard. In my view, three conditions work this unhealthy magic.

Present corruption simply could not be sustained without the complicity of the legal community. I am not referring just to the complicity required from those who make applications for judicial appointment. ${ }^{157}$ As important as that is, it is but an expression of a more general malaise. Lawyers feel free to pursue judicial office under corrupt conditions only because they are members of a community which either does not recognize, or does not care about, that corruption. That this is so is fundamentally corrosive of government by law. Felix Frankfurter famously declared that "[i]n the last

Schumer, supra note 6 at 27 .

About which, see R.A. Posner, Overcoming Law (Cambridge, MA: Harvard University Press, 1995) c. 4.

153

Legislation of this sort, I should reiterate, requires a political resolve on the executive's behalf to act as a Rule of Law government. Tragically, the present administration has no such resolve and seeks instead simply to maintain its arbitrary power to appoint. See J. Tibbetts, "PM Shows Little Interest in New Supreme Court Process" The National Post (3 May, 1999) A7; J. Tibbetts, "Chretien Keeps Control Over Choosing Judges" The National Post (19 June, 1999) A4; L. Chwialkowska, "Liberals Won't Be Opening System of Appointed Judges" The National Post (7 July, 1999) A7; and R. Foot, "Retired High Court Judge Opposes Calls for Reform" The National Post (29 October, 1999) A5. In a moment, I shall suggest why this might be so. Other contributions to this issue of the Alberla Law Review do, however, undertake this critical task.

13s Sztompka, supra note 67. See also P. Soper, A Theory of Law (Cambridge, MA: Harvard University Press, 1984) at 55-56, 80-84, 87-90.

L. Chwialkowska, "Poll Shows Canadians Divided on Judges' Power to "Make Law" The National Post (18 February 2000) A4.

157 
analysis, the law is what lawyers are." ${ }^{58}$ So viewed, the conditions of political community turn upon the quality of the men and women, individually and collectively, who compose the community of lawyers. So far as the judicial branch is concerned, "the main contribution that lawyers as a whole can make to the quality of the bench is to be true to their own standards as members of a learned profession." ${ }^{159}$ Where, as here, lawyers are the kinds of people who can (for whatever reason) acquiesce in abusive power, political association by Rule of Law (an independent judiciary especially included) is at least flawed and perhaps in serious jeopardy. ${ }^{160}$

Civic ignorance is a second, though related, condition. Were the citizenry educated politically ${ }^{161}$ it would not be seduced, as it presently is, by the "mythology, mystification, [and] noble lie[s]"162 which the federal state and especially the media continue to feed to it. ${ }^{163}$ Moreover, were this the happy case, citizens would demand, and the federal executive would then resolve to provide, ${ }^{164}$ government by law in the matter of judicial appointment. That this is not the case is not, however, unrelated to the legal community. In addition to the obligations with which lawyers are burdened individually (i.e., obligations to clients, to other lawyers, and to the bench), corporately lawyers have real obligations to society. Chief among these obligations is the duty to act as good faith guardians of the Rule of Law; included in this is the duty to educate the public on the meaning and requirements of government under law. Lawyers and law societies in Canada have forsaken this obligation. ${ }^{165}$ When lawyers on rare occasion do address the public, their voices are most often found joined with the media's cheery boosterism about individual judges. ${ }^{166}$

Lord Acton cautions us that "[t]here is no worse heresy ... than that the office sanctifies the holder of it." ${ }^{167}$ This wisdom, however, overlooks the possibility that

Letter from Felix Frankfurter, Professor, Harvard Law School, to Mr. Rosenwald 3 (13 May, 1927) quoted in H.T. Edwards, "The Growing Disjunction Between Legal Education and The Legal Profession" (1992) 91 Mich. L. Rev. 34 at 34.

Lederman, supra note 59 at 1179.

The legal community was not always so complacent before power. See Friedland's account of the role played in the past by the Canadian Bar Association and the Canadian Association of Law Teachers, supra note 99 at 234-40. And, of course, my comments are broad-brush. A number of lawyers continue to adopt an oppositional attitude towards this particular abuse of executive power. I think particularly of Jake Ziegel's long and lonely fight. See for example supra notes 4, 101 and 108.

161 About which, see W.A. Galston, "Civic Education" in Liberal Purposes: Good, Virtues and Diversity in the Liberal State (Cambridge: Cambridge University Press, 1991) at 241-56; A. Gutmann, Democratic Education (Princeton: Princeton University Press, 1987); and F.G. Gale, Political Literacy (Albany: State University of New York Press, 1994).

Waldron, supra note 67 at 58.

The media's role in this is especially regrettable and perhaps reaches its most repugnant debts in print journalism's gossipy assessments of competitions for Supreme Court appointments and subsequently in its boosterism for new appointees. See for example: Tibbetts, "PM Shows Little Interest in New Supreme Court Process," supra note 153; and M. Jimenez, "Arbour Takes More Than Star Status to Supreme Court" The National Post (11 June 1999) A4.

See supra note 153.

I shall refrain from comment on the Canadian Bar Association's "Law Day."

See for example, supra note 163.

Letter from Acton to Creighton (3 April, 1887) quoted in A. Schlesinger, Jr., "Intellectuals' Role: Truth to Power?" The Wall Street Journal (12 October 1983) 28. 
the opposite is sometimes the case. Sometimes, that is, it is the holder of the office who elevates an otherwise degraded office. This is the case, I believe, with respect to the federally appointed bench in Canada. Despite the corruption which attends the process of appointment - and, as I hope I have demonstrated, despite all of the corruption which that implicates - some judges, by reason alone of their personal authority, sanctify their offices. ${ }^{168}$ This force of individual moral character is the third buttress which sustains the authority of the court under present circumstances.

If I am correct, then, it is the combined effect of civic ignorance, the legal community's complicity in abusive power, and the very accidental force of certain good individuals which lends the appearance of legitimacy to the third branch of the Canadian state. If this meets Lord Devlin's condition, ${ }^{169}$ it does so only in the last regard. And that some good people will, despite the moral poverty of the process, sometimes happen to get appointed, I will conclude, is the thinnest ground conceivable for the authority of judicial office. 